BÖLCSKEI-FARKAS-SLíz szerk., Magyar és nemzetközi névtani terminológia. Hungarian and International Onomastic Terminology. International Council of Onomastic Sciences - Magyar Nyelvtudományi Társaság, Uppsala-Budapest, 2017. 29-47. DOI: $10.26546 / 5061110.7$

\title{
Nemzetközi és magyar névtani terminológiai kutatások
}

1. Bevezetés. E tanulmány az idegen nyelvü, nemzetközi, valamint a magyar névtani terminológia terén végzett eddigi munkálatokat, illetve eredményeket szándékozik főbb vonalaiban, vázlatosan bemutatni. Első része a nemzetközi névkutatással foglalkozik. Ennek során az idegen nyelvű névtani terminológiai szótárak, szójegyzékek palettájáról (2. pont), a terminológia kérdéskörének a külföldi onomasztikában való megjelenéséröl, illetve a névtani terminológiával foglalkozó fontosabb nemzetközi projektekről (3. pont) ad áttekintő képet. A tanulmány második, terjedelmesebb része a magyar névtani terminológia kérdéskörére fordítja a figyelmet. Sorra veszi az átfogó igényű rendszerezésére és leírására irányuló kezdeményezéseket (4. pont), valamint bemutatja a témakörnek a magyar szakirodalomban való megjelenését (5. pont). A tanulmány befejezéseképpen (6. pont) a nemzetközi és a nemzeti nyelvü (konkrétan: a magyar) névtani terminológia kapcsolatát, a vonatkozó munkálatok összefüggéseit, illetve főbb szempontjait vázolja fel az olvasó számára.

2. A nemzetközi névtani terminológiai irodalom. Különböző országok névkutatóinak munkájaként egy- és többnyelvü névtani terminológiai jegyzékek és szótárak egész sora készült el a 20. század második felétől napjainkig. Elsőként e terminológiai munkákról adok rövid áttekintést az alábbiakban.

2.1. A névtani terminológia módszeres feldolgozásában a német és a szláv nyelvü névkutatás bizonyult úttörő szerepünek. Az első ilyen munkák ugyanis az 1960-as években a német (WITKOWSKI 1964), majd egyes szláv nyelvek névtani terminológiájáról jelentek meg (ukrán: NIMCSUK 1966, szorb: PETR 1969, később majd orosz: PODOLSZKAJA $1978^{1}$ és $1988^{2}$ ). (A német és az orosz terminológiai szótár magyar ismertetéseit 1. FEHÉRTÓI 1966: 246-247, UDVARI 1981.) Nemzetközi szakmai együttmüködések révén, illetőleg ezeket is szolgálandó készültek el azután a német és egy tucatnyi szláv nyelv névtani terminusainak közös feldolgozásai (bővebben 1. BAUKO 2012: 157-158). Előbb a Základní soustava a terminologie slovanské onomastiky (német címén: Grundsystem und Terminologie der slawischen Onomastik) címü munka jelent meg 1973-ban (SVOBODA et al. 1973), amelyet pont egy évtizeddel később az Osnoven sistem i terminologija na slovenskata onomastika (más nyelvü címein: Osnovnaja sistema i terminologija slavjanskoj onomastiki. Grundsystem und Terminologie der slawischen Onomastik) címü összeállítás követett (BEZLAJ et al. 1983). A német névkutatás terminusairól azóta újabb összeállítás is született (WALTHER 1998), ahogyan több szláv nyelvéröl is. (Az ukránról, terminológiai szótárként, nyomtatásban: BUCSKO-TKACSOVA 2012; a lengyelről, terminológiai jegyzékként, elektronikus formában: GAŁKOWSKI 2012. A különböző szláv 
nyelvekre együttesen 1. még RZETELSKA-FELESZKO et al. red. 2002-2003. 2: 567-602. További szláv nyelvü névtani terminológiai jegyzékek munkálatai jelenleg, aktuálisan is folynak.)

Az észak-európai névkutatók ugyancsak elkészítették névtani terminológiájuk hasonló feldolgozásait (KIVINIEMI et al. 1974, SCHMIDT 1981). A nagyobb uráli nyelvek részéről - a magyar nyelv kivételével - szintén születtek ilyen jellegü összegzések (finn: a svéddel közösen, 1. KIVINIEMI et al. 1974; észt: HENNO-PÄLL 2003). (Az elöbbi munka magyar ismertetését 1. MIZSER 1979: 247-248.)

Készülttek terminológiai szótárak - egyaránt az észak-amerikai névkutatásnak köszönhetően - mind az angol nyelvü onomasztika (SMITH 1967, ROOM 1996), mind a (kanadai) francia nyelvű (hely)névkutatás (DORION-POIRIER 1975) terminusairól. Több nagy nyelv vonatkozásában ugyanakkor mindmáig hiányzik az említettekhez hasonló feldolgozás, mint például az olasz esetében (vö. GAŁKOWSKI 2010; 1. ugyanakkor FÁBIÁN 2001 kétnyelvü terminológiai jegyzékét, bővebben még később).

Külön emlitést érdemelnek az ENSZ Földrajzi Névi Szakértői Csoportjának (UNGEGN) munkatársai által elkészített speciális célú, valamint a Nemzetközi Névtudományi Társaság (ICOS) Terminológiai Munkacsoportja által összeállított átfogó igényü, kifejezetten nemzetközi felhasználásra szánt glosszáriumok. (Ezekről bővebben 1. még később.)

2.2. A korábban megjelent terminológiai jegyzékek, szótárak terminusai többé-kevésbé megszokottá, természetessé válhattak egy-egy nyelv névtani szakirodalmában. Ugyanakkor napjainkban is tapasztalható az a figyelem, amely a névkutatás terminológiájára és az ezzel összefüggő névelméleti problémakörökre irányul, s újabb terminológiai szójegyzékekre is mutatkozik igény és szándék. Megkezdődtek például a Szlovák Tudományos Akadémia kebelén belül múködő Névtani Bizottság irányításával - és nemzetközi közreműködéssel - egy szisztematikus elektronikus névtani terminológiai adatbázis összeállításának munkálatai. A készülő adatbázis az egyes terminusokat különböző információkkal (többek közt a más nyelvű - köztük a magyar nyelvi - megfelelőkkel) együtt szándékozik feldolgozni (1. BAUKO 2015b: 73). Az Osnoven sistem i terminologija na slovenskata onomastika címủ soknyelvủ (szláv és német) terminológiai szótár (BEZLAJ et al. 1983) újabb, bővített és átdolgozott kiadására már évekkel ezelőtt született javaslat (1. HARVALíK 2007).

A névtani terminológia problematikájára az újabb, összefoglaló jellegü és reprezentatív igényü külföldi, illetve nemzetközi névtani kézikönyvek gyakran külön figyelmet fordítanak. Akár módszeresen visszatérö kérdéskörként az egyes tematikus fejezetek bevezetéseként (pl. BRENDLER-BRENDLER Hrsg. 2004), akár önálló fejezetként (pl. WITKOWSKI 1995, KALETA 1998) - illetve e két módszert egyszerre alkalmazva (pl. MARCATO 2009: 10-13 és passim) -, akár pedig - az önálló fejezetek mellett - a mühöz csatolt terminológiai mutatók formájában (RZETELSKA-FELESZKO et al. red. 2002-2003. 1: 81-94, 2 : 567-602).

Az ICOS háromévente megszervezett nagyszabású nemzetközi névtani kongresszusain a névtani terminológia kérdésköre több alkalommal is (Pisa, 2005; Torontó, 2008; Barcelona, 2011) külön szekcióként jelent meg a programban, a téma fontosságát és a rá irányuló szakmai figyelmet egyaránt jelezve. Az ICOS-kongresszusok alkalmával ülésezik egyébként az ICOS terminológiai munkacsoportja is.

Konferencia-előadások, tanulmányok, folyóiratcikkek sora tárgyalja napjainkban a nemzeti és nemzetközi névtani terminológia általános, elméleti, metodológiai problémáit, 
illetve az egy-egy részterülettel, kérdéskörrel vagy akár egy-egy konkrét terminussal kapcsolatos specifikus kérdéseket. (A fontosabb továbbvezető irodalomhoz 1. pl. az ICOS terminológiai listáinak végén közölt válogatott bibliográfiákat a szervezet honlapján.)

3. A nemzetközi névkutatás terminológiai munkálatai. A különböző nyelvek kutatói, szakemberei közötti együttmüködések - különösen azok szervezettebb formái - természetszerüleg irányították rá a figyelmet a névtani terminológia, illetve a terminológiai harmonizáció kérdéseire. Mindezt gyakorlati lépések, szerveződések és munkálatok sora kísérte nemzetközi színtéren.

3.1. Az 1959-ben megrendezett első nemzetközi szláv névtudományi kongresszus nyomán alakult meg a Nemzetközi Szlavisztikai Komité Onomasztikai Bizottsága, s az ennek kebelén belül létrejött négy albizottság egyike a Terminológiai Albizottság lett (vö. WITKOWSKI 1995: 290). Ennek és a Német Tudományos Akadémia Szlavisztikai Intézetének az együttműködésével készült el az onomasztika fentebb említett első terminológiai szótári feldolgozása (WITKOWSKI 1964), mintegy hatszáz névtani terminussal. A testület a későbbi terminológiai munkálatokból is kivette a részét. (A szláv, különösen a csehszlovák, illetve a szlovák névkutatás terminológiai munkálatairól 1. még BAUKO 2012: 157-159.)

Az észak-európai országok névtudományi együttmüködését biztosító NORNA (alapítva 1971-ben) egyébként hasonlóan jó példával szolgált a névtani terminológia fontosságára. A NORNA által szervezett legelső szimpózium központi témáját a névtani terminológia problematikája képezte, amely a későbbi szimpóziumok során is fel-felbukkant a programban (GYÖRFFY 2007: 250).

3.2. Az ENSZ 1959-ben (akkor még más néven) felállított Földrajzi Névi Szakértői Csoportjának (United Nations Group of Experts on Geographical Names, UNGEGN) köszönhetően elöször 1984-ben, majd újabb, javított kiadásban 1987-ben jelent meg egy terminusgyüjtemény, mely a földrajzi nevek egységesítésében használt szakkifejezéseket adta közre. A kiadvány eredetileg az ENSZ hat hivatalos nyelvén látott napvilágot. (A második kiadás később magyar fordításban is megjelent: FöLDI 1992.) Az elkészült munka hiányosságainak kijavítására azonban már 1989-ben kezdeményezték egy terminológiai munkacsoport felállítását. A NAFTALI KADMON irányításával készült és szerkesztett, a napjaink helynév-standardizációs tevékenységéhez kapcsolódó terminológiát közreadó és értelmező újabb összeállítás közel négyszáz tételből áll, s ugyancsak a világszervezet hat hivatalos nyelvén jelent meg, 2002-ben (Glossary of Terms for the Standarization of Geographical Names). Ehhez azóta egy kisebb kiegészítéseket és javításokat tartalmazó Addendumot is kapcsoltak, s anyaga további nyelveken is megjelent. A szójegyzék folyamatos korszerüsítése, gondozása a munkacsoportnak továbbra is feladata. (Minderről bővebben, továbbvezető irodalommal 1. BÖLCSKEI 2017, kötetünkben. A hivatkozott alapdokumentumok elérhetők az UNGEGN honlapján.)

A földrajzi nevek nemzetközi standardizációja több nemzetközi szervezetet érintő tevékenység, melynek szükségképpen vannak terminológiai vonatkozásai. Erre ad példát a tengerfenék-domborzati nevek egységesítésének kérdésköre is. Az ehhez kapcsolódó irányelveket és útmutatót tartalmazó alapdokumentum a Nemzetközi Hidrográfiai Hivatal (International Hydrographic Bureau, IHB) kiadásában, több változatban és nyelven 
megjelent már. Angol-magyar nyelvű verziója, mely a megfelelő kétnyelvű terminológiai jegyzéket is tartalmazza (MÁRTON-DUTKÓ szerk. 2003: 17-30, újraközlését 1. MÁRTON 2012: 305-318), szintén rendelkezésre áll. Ennek a munkának is voltak hazai, a magyarországi Földrajzinév-bizottság müködéséhez kapcsolódó előzményei (FöLDI 1979, újraközléseit 1. MÁRTON 1992: 91-92, ill. 2012: 278-279; a témakör tudománytörténetéröl bővebben 1. MÁRTON 2012: 184-192).

3.3. A Nemzetközi Névtudományi Társaság, azaz az ICOS (International Council of Onomastic Sciences) keretei közt, a 2002-es uppsalai nemzetközi névtudományi kongresszuson MILAN HARVALÍK egy terminológiai munkacsoport létrehozását indítványozta (1. HARVALÍK 2005). A munkacsoport 2004-ben meg is kezdte müködését, melynek köszönhetően különböző nyelvek és névtani iskolák képviselőinek közremüködésével elkészült az alapvető terminusok - rövid meghatározásokkal és példákkal ellátott - listája. Ezt az ICOS három hivatalos nyelvén: angolul (ez volt a munkanyelv is), valamint németül és franciául tették közzé. E listák kiinduló változatát a 2005. évi ICOS-kongresszuson, Pisában, majd bővebb változatában 2011-ben, a barcelonai ICOS-kongresszuson mutatták be. A jegyzékek jelenlegi formájukban mintegy 70 terminus leírását tartalmazzák (Lists of Key Onomastic Terms). Ezek a terminológiai szójegyzékek elérhetők az ICOS honlapján. (Minderről bővebben 1. HARVALÍK 2014: 21-22, ill. BÖLCSKEI 2017, kötetünkben.)

Az ICOS a névkutatók tágabb körét igyekezett bevonni terminológiai munkacsoportjának tevékenységébe. Müködésének kezdetén például több, különböző országokból származó névkutatót megkerestek egy rövid, a terület általános problematikájára vonatkozó kérdéssorral, s a válaszokat és azok összegzett tanulságait közzé is tették (HARVALÍKCAFFARELLI 2007, magyar válaszadójuk FÁBIÁN ZSUZSANNA volt). Ebből a felmérésből is kiviláglott, hogy a névtani terminológia terén minden nyelvben egy sor - részben hasonló, részben eltérő - probléma, illetve feladat áll a kutatók előtt. Ezért az ICOS terminológiai munkacsoportja a fent említett terminológiai jegyzékek elkészítését követően további munkaterületekkel, illetve csoportokkal bővítette tevékenységét. Ezek célja egyrészt további nyelvek (és egyúttal kultúrkörök) számára is hozzáférhetővé tenni, illetve adaptálni az elkészült terminológiai jegyzékeket - mely munkába immár magyar kutatók is bekapcsolódtak -, másrészt pedig az egyes névtudományi részterületek terminológiáját módszeresen és részletesebben is feldolgozni.

3.4. Az ICOS és az UNGEGN névtani terminológiával foglalkozó képviselői a 2008. évi torontói ICOS-kongresszuson tartott egyeztető megbeszélés nyomán egy közös terminológiai munkabizottságot is létrehoztak. A két testület készítette terminológiai jegyzékek közt különböző típusú, részben szükségszerü, részben viszont csökkenthető különbségek találhatók. (Minderről bővebben 1. NYSTRÖM 2014, vö. VASILEVA 2014 is.) A két szervezet összehangoltabb munkája - melyet személyi átfedések is elősegítenek - természetszerüleg csak nyereséggel járhat az érintett szakterületek számára.

3.5. Az UNGEGN, illetve az ICOS itt említett névtani terminológiai jegyzékeinek további nyelveken való kiadására egyelöre néhány példát ismerünk csupán. Magyar változatuk e tanulmánnyal együtt jelenik meg, nyomtatott és elektronikus formában. 
4. Törekvések a magyar névtani terminológia átfogó igényű rendszerezésére és leírására. A magyar névtudomány terminológiájának, illetve egyes terminusainak a problematikáját alkalmilag, illetve érintőlegesen többen is tárgyalták már. E szakterület müszóhasználatának kérdésköréről azonban csak a hetvenes években, a magyar névtudomány dinamikus szerveződésének időszakában bontakozott ki tágabb körü, átfogó igényü eszmecsere. A kezdeményező szerep - mint oly sok más területen is - HAJDÚ MIHÁLYé, a magyar névkutatás későbbi első számú szervező egyéniségéé volt. (L. a leginkább illetékes visszaemlékezéseit is: HAJDÚ 2010: 24-26.)

4.1. Vitaindító a névtudomány műszavairól címmel 1974-ben készült el és lett szétküldve - stencilezett kiadványként - az ún. Bokor Levelek 12. száma (HAJDÚ 1974a; kisebb változtatásokkal később a Névtani Értesítőben is: HAJDÚ 1979). Anyagát az ifjabb nyelvész generációk egykori szakmai-baráti körének, a Bokornak az egyik összejövetelén vitatták meg, míg többen írásbeli hozzászólásaikat juttatták el a kezdeményezőhöz. A javaslatok nyomán egy tartalmilag és formailag egyaránt jócskán átdolgozott, konkretizált változat (HAJDÚ 1974b) készült az anyagból. (Erre azért is szükség volt, mert az eredeti szöveg ténylegesen vitaindító formájában lett megfogalmazva.) Az újabb anyagot azután az eredeti szándéknak megfelelően a Magyar Tudományos Akadémia - akkor még létező - névtudományi munkabizottságához terjesztették fel.

Az említett elöterjesztésben megfogalmazott elvek a következők voltak: bizonyos fokú egységesítés (a stilisztikai vagy célszerüségi szempontú szinonimitás lehetséges megtartásával); a már konvencionalizálódott műszavak megtartása (szemben az elméleti nézőpontból indokoltnak látszó újításokkal); a jobban használható (rövidebb, kifejezőbb, jobban képezhető) terminusok preferálása. A tervezet az alapvető szempontok megfogalmazását követően mintegy kéttucatnyi szinonimapárt, illetve szinonimasort vett számba, a köztük lévő választásra téve vagy kérve javaslatot. A további kérdéseket - mint nem csupán terminológiai problémákat - az előterjesztő ,elvi cikkek sorozata” után látta megoldhatónak.

Az előterjesztés végezetül, a témához kapcsolódóan egy, a névkutatás müszavait is számba vevő kiadvány - MEZÖ ANDRÁs javaslata nyomán immár egy névtani lexikon tervét ismertette röviden. A javasolt névtani lexikon elkészítésének az elvei a következők lettek volna: minden egykor előfordult müszó vagy körülírás felvétele; szükségesnek tünő új müszavak alkotása; szinonimák (esetleg kerülendőnek tartott kifejezések) felvétele a preferált megnevezésre utalóan; egyes kifejezéseknek akár egy nagyobb szócikk részeként való tárgyalása. Az addig összegyüjtött címszavak száma közel ötezer volt, a tervezett munka pedig nagyságrendileg 3-4 ezer önálló szócikkből állt volna. Amint azt a mutatványként eredetileg mellékelt címszólista is jelezte, HAJDÚ és MEZŐ javaslata valóban inkább enciklopédikus jellegü, mint szótárszerü feldolgozásra irányult. HAJDÚ egyik visszaemlékezésében a ragadványnevek témaköréhez (és betürendjéhez) kapcsolódó tervezett címszavakat idézi is e tervezetből (HAJDÚ 2010: 25; a fogalomkör terminusaira egyébként 1. BAUKO 2009: 7-9). A konkrét müszavak mellett e mutatványban is egy sor lexikonszerű címszó kapott helyet, s nemcsak utaló, de önálló szócikként is (pl. ragadványnevek keletkezési inditékai, ragadványnevek nyelvi eszközei, ruházatra utaló ragadványnevek $\mathrm{stb}$.).

Az akadémiai munkabizottság a nagy tekintélynek örvendő Bárczi Géza vezetésével a következő évben megtárgyalta és támogatandónak találta a kezdeményezést. Nem sokkal 
később azonban Bárczi elhunyt, s az akadémiai átszervezések kapcsán maga a bizottság is megszüntette müködését. A kérdés így egy időre lekerült a napirendröl.

4.2. A problémakör újabb felvetését a magyar névkutatás folyóiratának, a Névtani Értesítőnek a néhány évvel későbbi megindulása tette egyrészt lehetővé, másrészt indokolttá. Az 1979-ben megindult periodika szerkesztője, HAJDÚ MIHÁLY egy rövid bevezetővel, kisebb változtatásokkal adta közre az eredeti vitaindítót a folyóirat hasábjain (HAJDÚ 1979). A témához kapcsolódóan több, különböző generációhoz tartozó névtanos kolléga: RÁCZ ENDRE, BACHÁT LÁSZlÓ, SZABÓ T. ATTILA, illetve ÖRDÖG FERENC és MÉSZÁROSNÉ VARGA MÁRIA, valamint a vitaindító HAJDÚ MIHÁLY hozzászólása is megjelent a folyóirat első számaiban (Névtani Értesítő 1979. 2: 28-34, 1980. 3: 56-60). Egyes terminusok kérdéséhez a folyóirat első évfolyamait recenzeáló KÁLMÁN BÉLA is hozzáfüzte megjegyzéseit (KÁLMÁN 1982: 502-503). Ekkoriban már több külföldi névtani terminológiai szótár hazai recenziója is olvasható volt Magyarországon (a német, finn-svéd, orosz munkáké: FEHÉRTÓI 1966, MIZSER 1979, UDVARI 1981).

$\mathrm{Az}$ ígéretes módon újraindult eszmecsere azonban ismét megszakadt. Más, nagyszabású hazai nyelvtudományi tervmunkák időszakában ez a téma tényleges támogatást nem kapott, kezdeményezőit pedig egyéb szakmai feladatok kötötték le. Mindemellett, úgy tünik, a névtani terminológia rendszerezésének, egységesítésének gondolata az akkori magyarországi névkutatókat sem érintette meg kellő mértékben. (Mindehhez 1. HAJDÚ 2010: 26, vö. HOFFMANN 2003: 54.)

4.3. A következő figyelemre méltó - s több szempontból újszerü - kísérlet bő két évtizeddel később, a 2000-es évek legelején történt a magyar névtani terminológia számbavételére. A VÁRNAI JUDIT SzILVIA nevéhez füződő, gyakorlatias megközelítésű angolmagyar névtani glosszárium egy nagyobb - több nyelvészeti területre kiterjedő - munka része, kezdeti lépése lett volna (VÁRNAI szerk. é. n.). Az interneten közzétett kétnyelvü, kísérleti célúnak szánt, 172 tételből álló puszta szójegyzék egy akkor indult kiadványsorozat fordítói munkálataihoz kapcsolódott: az Onomastica Uralica címü, angol és orosz nyelven megjelenő, magyarországi hátterü névtani periodika aktuális kötetének (2. History of the Study of Toponyms in the Uralian Languages. Debrecen, 2002) elkészítéséhez. (Ez a konkrétum magyarázhatja tematikus kiegyensúlyozatlanságát, ti. a helynévkutatás terminusainak felülreprezentáltságát is a listában.)

$\mathrm{Az}$ interneten ma is elérhető kétnyelvü glosszárium előszava szerint az itt közzé nem tett részek további járulékos információkat tartalmaztak (szükség esetén tömör definíciót, megjegyzést, szakirodalmi hivatkozást, esetleges rövidítést, szófaji besorolást, kereszthivatkozásokat). Az előszó emellett folyamatban lévő és folytatólagos munkálatokról adott hírt. A projekt azonban sajnos félbeszakadt, a tervezett nagyobb munka nem készült el, s háttéranyagainak sorsáról sincs tudomásunk. (VÁRNAI későbbi, névelméleti kérdéskörökkel foglalkozó doktori disszertációjában nem is érinti a névtani terminológia akár elméleti, akár gyakorlati, akár tudománytörténeti kérdéseit; vö. VÁRNAI 2005.)

Időrendi és tematikai szempontból egyaránt itt kell említést tennünk egy nyomtatásban megjelent, olasz-magyar névtani terminológiai glosszárium elkészültéröl is (FÁBIÁN 2001). Anyagában a címszóként szereplö, fontosabb olasz névtani terminusok olasz nyelvü értelmezéssel, magyar megfelelővel és/vagy értelmezéssel, valamint különböző nyelvü névtani példákkal szerepelnek. Az összeállítás egy magyarországi olasz szakos egyetemi 
hallgatóknak készült, az olasz névkutatás különböző területeiről bőséges válogatást adó tanulmánygyüjtemény részeként - egyfajta függelékeként - jelent meg.

Az itt említett kétnyelvü, magyar párú névtani terminológiai jegyzékeket az összeállítóik egyaránt az idegen nyelvi szakkifejezések szerint rendezve - azaz az idegen nyelvről a magyarra való fordítás, értelmezés iránya szerint - tették közzé. Magyar terminusok szerint rendezett változatuk, illetve magyar terminusmutató nem jelent meg mellettük.

4.4. Egy magyar névtani terminológiai szótár elkészítésére, ennek egyes szempontjaira, illetve lehetőségeire alkalmilag mások is tettek javaslatot a későbbiekben. A következő évek magyar névtani konferenciáin egy-egy névtani terminológiai vonatkozású előadás is hasonló felvetésekkel élt, lényegében a konkrétan tárgyalt problematikából levont konzekvenciaként (JUHÁsz 2004: 165-166, FARKAS 2008: 339-340). E felvetéseket tényleges elhatározás és konkrét lépések ugyanakkor nem követték. A magyar névtani terminológia módszeresebb vizsgálatának így néhány névkutató (Bölcskei Andrea, Slíz Mariann és, Farkas Tamás) összefogása adhatott újabb lendületet: az ICOS terminológiai munkabizottságának magyar alcsoportját megalkotva egyúttal a két legfontosabb nemzetközi névtani terminológiai jegyzék magyar változatának elkészítésére is vállalkoztak. A magyar névtani terminológiával való módszeres foglalkozás szándékát tehát az aktuális nemzetközi névtani terminológiai munkálatok, illetve a magyar és a nemzetközi névtani terminológia közti harmonizáció igénye is erőteljesen inspirálták.

Az alapvetően informális jellegü, de tervezett kutatói együttmüködés alapján, illetve ahhoz is kapcsolódóan 2010 után több irányban történtek lépések. Áttekintés készült a nemzetközi és a magyar névtani terminológiai munkálatok tudománytörténetéröl és aktuális állásáról (FARKAS 2011). Egy Névtan és terminológia címmel, úttörő jelleggel megrendezett workshop a témakör több alapvető kérdéskörét vitatta meg, előadások és egy kerekasztal-beszélgetés formájában (vö. BÖLCSKEI-FÓRIS 2012); az elhangzott előadásokat a Névtani Értesítő 2012. évi kötete tette közzé (HOFFMANN 2012, FARKAS 2012, SLÍZ 2012, BÖLCSKEI 2012, BAUKO 2012). Az elmúlt években módszeresebb figyelemben részesült továbbá a magyar névtani terminológia több általános jellegü, illetve tematikus kérdésköre, akár e kifejezetten terminológiai érdekü munkálatokhoz kapcsolódóan, akár a magyar névkutatás egyéb témaköreiben végzett feldolgozó munka eredményeként. (A módszeresebben vizsgált kérdéskörökről 1. a későbbiekben.)

Az említett kutatói együttmüködéshez kapcsolódóan kezdődtek meg az UNGEGN nemzetközi helynév-standardizációs terminusjegyzéke magyar változatának munkálatai (vö. BÖLCSKEI 2013a), majd pedig - ugyancsak BöLCSKEI ANDREA irányításával - az ICOS nemzetközi névtani glosszáriumát érintő hasonló munkák. (Mindkét projektről részletesebben 1. BÖLCSKEI 2017, kötetünkben.) Tervezet született egy átfogó igényü, korszerü magyar névtani terminológiai szótárra, annak elkészítési folyamatára és fö jellemzőire vonatkozóan is (FARKAS 2013). Az ezen munkálatoknak keretet adó, illetve a hátteret biztosítani hivatott kutatási pályázat azonban sajnos nem részesült támogatásban. A megkezdett munkák viszont folytatódtak, s míg az önálló magyar névtani terminológiai szótár megvalósítása továbbra is távlati cél maradt, az említett nemzetközi névtani terminológiai jegyzékek magyar változatai már a névkutatók rendelkezésére állnak. A két névtani terminológiai glosszáriumot és a kapcsolódó tanulmányokat - köztük ezt az írást is - közreadó kétnyelvü kötet szintén az említett kutatói együttmüködés keretében készült el. 
4.5. A magyar névkutatás fejlődését segítő kézikönyvek köréből (vö. HoFFMANN 2002: 16-17; bár az itt jelzett hiányok azóta egyébként csökkentek) továbbra is hiányolnunk kell egy átfogó igényü, részletes és módszeres magyar névtani terminológiai szótárat. Ezzel kapcsolatban hadd idézzem itt csupán az utóbbi évtizedek magyar névtudománya két iskolateremtő személyiségének véleményét. HAJDÚ MIHÁLY megítélése szerint „,[k]orunk egyik legégetőbb kérdése a névtani terminológia egységesítése" (HAJDÚ 2011: 345). S bár HAJDÚ megfogalmazását joggal árnyalhatnánk, az bizonyosnak látszik, hogy - immár HOFFMANN ISTVÁNt idézve - „[e]gy ilyen munka még akkor is elősegíthetné a tudományterület átláthatóbbá tételét és talán e tekintetben való némi egységesülését is, ha összeállítói inkább tájékoztató, semmint normaadó szándékkal gyüjtenék egybe a névtani szakirodalomban használatos fogalmak jelölöit" (HOFFMANN 2003: 55). Ezek a megállapítások összhangban is állnak a szóban forgó munka elkészítésére vonatkozó újabb (fentebb már hivatkozott) elképzelésekkel.

Egy magyar nyelvü - ugyanakkor a nemzetközi névtani terminológiára is tekintettel lévő - névtani terminológiai szótár elkészítését így továbbra is a magyar névkutatás előtt álló feladatnak tekinthetjük. Egy ilyen szakmunka hasznosnak bizonyulhatna nemcsak a hazai és a nemzetközi névtudomány, hanem más, kapcsolódó tudományterületek szempontjából, valamint a mindezek közötti szakmai kommunikáció, illetve együttműködések megkönnyítésében is (vö. FARKAS 2013: 445).

5. A névtani terminológia problematikája a magyar szakirodalomban. Az alábbiakban egyrészt a névtani terminológia általános helyzetével, kérdéseivel foglalkozó magyar szakirodalomról igyekszem átfogó képet adni, másrészt az egyes névtani részterületekhez, témakörökhöz kapcsolódó szakirodalomról - immár szükségszerüen csupán vázlatosabb - áttekintést nyújtani.

5.1. A névtani terminológia általános - azaz nem egy-egy konkrét névtudományi kérdéskörre vonatkozó - problémáiról viszonylag kevés tanulmány született mindeddig a magyar névtani szakirodalomban. Ide sorolhatók egyrészt a magyar névtani terminológia átfogó, rendszerező igényü leírására irányuló, azt szorgalmazó munkák (ezekről bővebben 1. a korábbiakban). Ide tartoznak másrészt azok a tanulmányok, amelyek elméleti igénnyel vizsgálják e terminológia jellemző sajátságait, rendszerint kiemelt figyelmet fordítanak annak problematikus vonásaira, példáikat pedig általában a névtan különbözö területeiről választják. Ilyen írások föleg az utóbbi néhány évben születtek, a következő témakörökre, aspektusokra fordítva figyelmüket: mi számít terminusnak (SLíz 2012); elmélet és terminológia összefüggései a terminushasználat és terminusalkotás szempontjából (HOFFMANN 2012); a terminusok létrejöttének okai, a terminushasználat változását befolyásoló tényezők, e változások következményei (SLÍz 2012); terminológiai hiányok (FARKAS 2012, SLÍz 2014); jelentéstani viszonyok, értelmezési problémák általában és a terminushasználat különböző színterein (FARKAS 2012, SLÍZ 2014); a nemzetközi hátterü és a magyar nyelvi eredetü terminusok problémái (FARKAS 2012, SLÍz 2014); a terminológiai egységesítés és harmonizáció kérdései (BÖLCSKEI 2012, 2017); a magyar és más nyelvek névtani terminológiájának módszeresebb összevetése (BAUKO 2012, SLÍZ 2014).

A névtani terminológia kérdésköre némi célzott figyelmet kapott egy tudománytörténeti összefoglaló munkában (HOFFMANN 2003: 53-55), illetve a magyar névkutatás közelmúltját és jelenét áttekintő és értékelő kötet keretein belül is (SLÍZ 2015: 101-103). 
A terminológiai problémák legtipikusabban azonban egy-egy aktuálisan tárgyalt részterület, témakör, valamely konkrétan vizsgált névtani kérdés kapcsán bukkannak fel a szakirodalomban. Az egyes összefoglaló munkák, adott témáról készült monográfiák, áttekintő igényü vagy éppen nagyon is speciális témájú tanulmányok gyakran nem is kerülhetnék ki, hogy foglalkozzanak a kapcsolódó terminológia kérdéseivel.

5.2. A következőkben a magyar névtani szakirodalomban legjellemzőbbnek tünő témaköröket és terminológiai vitatémákat igyekszem bemutatni, a névtan egyes részterületei szerinti áttekintésben. Részletes, módszeres és teljes körü feldolgozásra természetesen itt nem vállalkozhatom, ezért hivatkozásaimban is elsősorban az utóbbi évek vonatkozó munkáira fogok utalni. Ezek ugyanakkor továbbvezető irodalomként szolgálnak a korábbi vonatkozó szakmunkákhoz is.

5.2.1. A magyar névkutatás (újbóli) fellendülésének, illetve a tudományterület önállósodásának a jeleként az 1950-es évek második felében némi figyelmet vívott ki magának a szóban forgó diszciplína, azaz az onomasztika magyar megnevezésének kérdése (PAPP 1955: 258, MIKESY 1960, BENKÖ 1960). A felmerült kérdéseket ezúttal is az idő oldotta meg: a szakterület egyes lehetséges megnevezései nem tudtak meggyökeresedni, illetve idővel kiszorultak a használatból. Több megnevezése azonban ma is használatos, szinonimákként (névtan, névkutatás, névtudomány, illetve onomasztika) a tudományos használatban (HOFFMANN 2012: 127-128).

5.2.2. A helynevek témaköréhez kapcsolódik a magyar névkutatás egyik legtöbbször - és hosszú időn át, vissza-visszatérő módon, különböző érvek és ellenérvek alapján vitatott terminológiai kérdése: a helynév vagy földrajzi név problémája. Mindkét terminus ma is aktív használatban van, a közülük való választást inkább egyéni, s részben tudományterület szerinti preferenciák jellemzik. (Minderről részletesebben 1. HoFFMANN 2003: 53-55, 2012: 128-130.) Magának a helynévkutatásnak a megnevezése alig bizonyult kérdésesnek, és a helynévtan egyéb terminusainak a témaköre is - a szükségszerüen meglévő változatosság, illetve az elméleti megközelítések eltérései mellett - általában kevésbé tünt problematikusnak (áttekintően 1. HoFFMANN 2012: 130-132).

Meghatározó terminológiai újításokat hozott magával viszont - szükségszerüen - egy új (hely)névrendszertani leírási modell (HoFFMANN 1993, 1999), mely az erre épülő további szakirodalom révén részleteiben is gazdagodott még (1. HoFFMANN 2012: 133-135). Fontos utalnunk továbbá arra, hogy mivel a HOFFMANN-féle névrendszertani modell más névfajták leírására is jól alkalmazhatónak, illetve adaptálhatónak bizonyult (vö. HOFFMANN $2007^{2}$ : 7-8), a vele együtt bevezetett terminológia a magyar névkutatás más területein is ismertté és használatossá vált.

Külön sajátos témakörként kell utalnunk a nemzetközi helynév-standardizáció magyar terminológiájára, melyröl a fentebbi, nemzetközi vonatkozású részben már részletesebben esett szó (áttekintően 1. még BÖLCSKEI 2017, kötetünkben). E tevékenységgel kapcsolatban a különböző nyelvekbeli terminusok harmonizációjának kérdése, a hiányzó terminusok bevezetése, a meglévő terminusok pontos definiálása játssza a meghatározó szerepet. (Magának a helynév-standardizációs tevékenységnek a megnevezésére szolgáló terminusokat egyébként 1. BöLCSKEI 2012: 176.) Mint tudjuk, akár egyetlen terminus értelmezése is számos elvi és gyakorlati problémát vethet fel; erre szolgáltat különösen 
szemléletes példát a nemzetközi helynév-standardizáció témaköréből az exonima problematikája (vö. pl. POKOLY 2013, POKOLY-BÖLCSKEI-MIKESY 2015). A nemzeti nyelven értelmezhető standard név(változat) fogalma természetesen további terminológiai kérdésekkel függ össze (vö. GYŐRFFY 2012).

5.2.3. A személynevek témakörében elsősorban az egyes személynévfajták megnevezése bizonyult problematikusnak. Már csak azért is, mert az itt különösen jellemző, a mindennapi tapasztalatból, illetve a köznyelvből származó alapvető terminusok szakmai szempontból gyakran vitathatók, mégpedig áttetsző közszói jelentésük, a bennük kódolt szemléletmód, valamint a megnevezendő névfajták időbeli, illetve a nyelvi-kulturális kontextus szerinti változatossága miatt. A magyar és más nyelvek közti viszonylatban például konkrétan a családnév + keresztnév névsorrend eltérése is speciális terminológiai problémák forrása. A magyar nyelvi eredetű terminusok igen gazdag, névelméleti és névtörténeti hátterü lehetséges nehézségeit e témakör különösen jól példázza (FARKAS 2012: 142-144).

Az itt felmerülő problémákat azok a névtani feldolgozások jelezték, illetve mutatták be a legvilágosabban, amelyek a teljes (személy)névrendszert kívánták módszeresen és következetesen áttekinteni (vö. HoFFMANN 2008: 5-8). J. SOLTÉSZ KATALIN fontos névelméleti monográfiájában (1979) több terminológiai újítással próbálkozott, kevéssé eredményesen (értékelésükre 1. HAJDÚ 1981: 109-110 is). Az újításokra egyébként mindig nyitott HAJDÚ MIHÁLY összefoglaló munkájában (2003) viszont elsősorban az ismert terminusok áttekintésével, mérlegelésével és a köztük való választással igyekezett megoldani a problémát (HAJDÚ 2003: 151-153, 347, 638, 732; nem véletlenül emeli ki és részletezi terminológiai módszerességét egyik recenzense is: B. GERGELY 2007: 253-255). A használatban lévő terminológia áttekintése és értékelése akár interdiszciplináris vonatkozásai miatt is fontos és releváns feladatnak bizonyulhat (1. pl. egy készülő személynévjogi kötet kapcsán; SLíz megj. e.). Ugyanakkor a személynévrendszerek olyan újszerü elméleti áttekintése, mint amit HOFFMANN IsTVÁNnál olvashatunk (2008), szükségszerűen új terminusokat igényelt és vezetett be a magyar személykutatás terminológiájába (bár eredetileg nem a határozott terminusalkotás, hanem a lehetőségek felvetésének igényével; 1. HOFFMANN 2008: 10, 1. lábjegyzet). A személynévtípusok rendszerének, alá- és fölérendeltségi viszonyainak további átgondolása ugyanígy újabb megoldandó terminológiai kérdésekhez vezethet el (vö. SZENTGYÖRGYI 2016).

A magyar személynévtani terminológia tisztázása aktuális kérdésnek számít a többek által és sokat vizsgált történeti személynévtípusok esetében (részletesen 1. SLíz 2010), de az alig kutatott személynévfajták, így a J. SOLTÉSZ KATALIN - egyébként erősen vitatható terminusával helyettesitő nevek-ként megnevezhető névfajták vonatkozásában is (J. SOLTÉSZ 1979: 59; ezekhez 1. még HAJDÚ 2006). Az újonnan létrejött személynévtípus, az internetes azonosítónevek (nicknevek) kategóriája pedig nyilvánvalóan új terminus(ok) használatba vételét igényelte (bővebben 1. RAÁTZ 1999: 263, 2008: 444; vö. HAJDÚ 2006 is).

A személynévtani terminológia az egyes névfajták megnevezése mellett természetesen egyéb témaköröket is érint. Egy konkrét kutatási projekthez kapcsolódóan például a személynév-, illetve a családnév-változtatások kérdésköre is kiemelt figyelemben részesült. Egyrészt a kapcsolódó (és meglepően gazdag) történeti és jelenkori, köznyelvi és szaknyelvi szóhasználat elemzése révén (FARKAS 2008), másrészt a (személy)névváltoz(tat)ások tipológiájának a javasolt terminológiai innovációkkal történő leírásának 
köszönhetően (HAJDÚ 2009, VÖRÖS 2009). E témakör egy általánosabb névrendszertani leírási keretbe illesztve viszont ismét más - azonban korábbi munkákból jórészt már ismert (vö. HOFFMANN 1993, 1999, ill. TÓTH V. 2008, N. FODOR 2010: 115-120) - terminusokkal válhatott leírhatóvá (vö. FARKAS 2015b).

5.2.4. A helynevek és a személynevek mellett az egyéb névtípusok (valamint a határterületek) vizsgálata nagyságrendekkel kisebb figyelmet kap a magyar névkutatásban. Az elméleti kidolgozatlanságot olykor a terminológiai hiányok is jelzik; például az, hogy az ide tartozó névtípusokat, illetve azok többségét összefoglalóan megnevező terminus (szemben a nemzetközi szakirodalomban bevett krematonima megnevezéssel; FARKAS 2012: 145) nem áll rendelkezésünkre. A terminológiai innováció, illetve rendezés elsősorban az adott névtani témakörre vonatkozó rendszerszerű kutatások elmélyítésétől várható (1. pl. az épület-, építmény- és létesítménynevek témakörének példáján: HÁRI 2010).

$\mathrm{Az}$ irodalmi névtan területén ugyanakkor élénk és termékeny terminológiai gondolkodásról adhatunk számot újabban. E téren KOVALOVSZKY MIKLÓS 1934-ben megjelent, Az irodalmi névadás címü klasszikus munkája sokáig erőteljesen befolyásolta a szakmai szóhasználatot. Az irói, illetve az irodalmi névadás fogalomkörének tisztázása így több mint fél évszázaddal ezelött és napjainkban is egyaránt aktuális feladatnak tünhetett (MIKESY 1959, ill. KorOMPAY 2011, valamint T. SOMOGYI 2015: 208, TÓTH L. 2015: 203-206, VÁCZINÉ TAKÁCS 2016: 9-18). Az összefoglaló értelemben - s részben az itt említett terminusok helyett is - bevezetett irodalmi névtan kifejezés maga is friss terminológiai újításnak tekinthető (vö. TÓTH L. 2015: 206, ill. VÁCZINÉ TAKÁCS 2016: 17). Az irodalomban előforduló nevek különböző típusainak megnevezése - KOVALOVSZKY (1934) és mások korábbi, klasszikus munkáihoz képest - a kérdés elméleti átgondolását és terminológiai kidolgozását egyaránt joggal igényelte (1. pl. TÓTH L. 2015, VÁCZINÉ TAKÁCS 2016). A közelmúltban elkészült, illetve készülőben lévő doktori disszertációknak köszönhetően e részterületen számottevő elörelépések történtek, illetve várhatók még a következő években is.

5.2.5. A névkutatás további részterületeit, illetve aspektusait jelentik a nyelvhasználat különböző dimenzióihoz: az időbeliséghez, a térbeliséghez és a társadalmi(-kulturális) meghatározottsághoz kapcsolódó kutatások. E részterületek közül a legnagyobb hagyománnyal bíró történeti névtan (névtörténet) megnevezése sosem volt kérdéses, de kevéssé bizonyul problematikusnak a legfiatalabb részterület, a szocioonomasztika (avagy: névszociológia) elnevezése is. E terminusok a megfelelő nyelvtudományi diszciplínák bevett megnevezésének pontos megfelelői. (Ezekhez l. FARKAS 2014a, kül. 14-17.) A névhasználat területi változatosságát kutató részterületnek (illetve egyes kérdésköreinek) az elnevezésével viszont visszatérő módon foglalkozott a szakirodalom, különböző terminusokat ajánlva, illetve a használatban lévő vagy felmerült terminológiai megoldásokat értékelve. Ennek kérdését a dialektológiai kutatásokkal is foglalkozó névkutatók tartották napirenden az elmúlt évtizedekben (1. különösen ÖRDÖG 1989: 29, 1991, 2010; HAJDÚ 2002; JUHÁSZ 2004: 166-169, 2010: 31; a témakör újabb összefoglalására 1. FARKAS 2014a: 15, értékelésére is N. FODOR 2014: 24-27). A szóba került terminusok közül napjainkban mindenesetre a névföldrajz (vö. nyelvföldrajz) látszik a leginkább használatosnak. 
6. A nemzeti nyelvü névtani terminológia a nemzetközi névkutatás kontextusában. Legvégül, összefoglaló jelleggel is érdemes arra irányítani figyelmünket, hogy a nemzetközi és a magyar névtani terminológia, illetve a vonatkozó kutatások miképpen kapcsolódnak össze egymással.

6.1. A magyar névkutatás terminológiáját általában a magyar nyelvü terminusok jellemzik, az idegen nyelvi eredetüek kevéssé számítanak tipikusnak mellettük (FARKAS 2012: 141-142, SLÍZ 2014: 249-252). A nemzetközi terminusok közvetlen átvétele nem túl gyakori, az ezek inspirálta innovációk pedig különösen ritkák. (L. BAUKO JÁNOS speciális jelentésü, egyedi használatú, a szláv nyelvekben egyébként bevett terminológiai mintákat tükröző terminusait: gasztroantroponima, orohodonima; vö. BAUKO 2015a: $76,127$.$) Megjegyezhetjük ugyanakkor, hogy a magyar nyelvü, megszokott névtani ter-$ minusok közt akadnak olyanok, amelyek esetében elképzelhető az idegen - konkrétan: német - nyelvi minta követése, illetve tükörfordítással való keletkezésük. Ilyenek például a névkutatás (Namenforschung) és a helynév (Ortsname) terminusok (FARKAS 2012: 142).

Mindezek mellett előfordulhat az is, hogy magyar névtani terminusok, terminológiai innovációk idegen nyelvü megfelelőinek megalkotására, lefordítására van szükség. Ez a helyzet például a HOFFMANN-féle elméleti modellekre alapuló idegen nyelvű közlemények esetében (1. pl. HOFFMANN 1993: 153-162, TóTH V. 2005, HOFFMANN-TóTH 2015).

6.2. Más nyelvek névtani terminológiája, illetve a nemzetközi névkutatás terminológiai kérdésekkel való foglalkozása elméleti és gyakorlati haszonnal egyaránt járt a magyar névtudomány számára. A magyar névtani terminusok problematikáját érintő, illetve tárgyaló írások nem ritkán más nyelvek vonatkozó névtani terminológiájára, szemléletének tanulságaira is kitekintéssel íródtak, íródnak. Ez a többé vagy kevésbé kutatott részterületek, a hagyományosabb vagy az újabb terminusok esetében egyaránt elörevivőnek bizonyulhat (vö. pl. MIKESY 1960, HAJDÚ 2003: 151-153, VINCZE 2004: 187-188, FARKAS 2008: 336, RAÁTZ 2008: 444, BÖLCSKEI 2010: 84-85, HÁRI 2010: 102-103, TÓTH L. 2015). A nemzetközi és a magyar névtani terminológia bizonyos jellemzőinek összevetésére (SLíz 2014: 249-252), illetve különböző nyelvek névtani terminológiájának összehasonlítására (módszeresen, szlovák, illetve szláv vonatkozásban: BAUKO 2012; egy szükebb témakörben, finn-magyar összevetésben: TAKÁCS megj. e.) ugyancsak akadnak példák a magyar szakirodalomban.

Fontos feladat a vonatkozó magyar kutatási eredmények nemzetközi megismertetésének és hasznosíthatóságának biztosítása is. Néhány, a magyar névtani terminológia sajátságait, egyes kérdéseit tárgyaló tanulmány a közelmúltban idegen nyelven látott napvilágot (BÖLCSKEI 2013b, FARKAS 2014b, BAUKO 2015c). Az ICOS és az UNGEGN nemzetközi, több nyelven is elérhető névtani terminológiai glosszáriumának magyar (illetve magyar párú) változatát, valamint a kísérő tanulmányokat most közrebocsátó kötet pedig eleve kétnyelvü tartalommal, angol és magyar nyelven jelenik meg.

6.3. Az ICOS, illetve az UNGEGN aktuális nemzetközi névtani terminológiai jegyzékének magyar változata mellett rendelkezésre áll néhány korábban megjelent, kétnyelvü, magyar párú névtani glosszárium is (ezekről 1. már a fentebbiekben).

Megjegyzést érdemel továbbá, hogy magyar névkutatók is bekapcsolódtak az ICOS terminológiai munkacsoportjának tevékenységébe, és van magyar anyanyelvü résztvevője 
a szlovák névkutatók által megkezdett, többnyelvü elektronikus névtani terminológiai adatbázis munkálatainak is, amelyben a magyar terminusok is helyet kapnak majd (BAUKO 2015a: 73).

6.4. A hasonló munkák jól támogathatják a magyar és a nemzetközi névkutatás (illetve a kapcsolódó tudományterületek) közötti szakmai kommunikációt, melyhez elengedhetetlen a terminológiai megfelelések ismerete. A nemzetközi és a nemzeti nyelvű névtani terminológiára fordított együttes figyelem ugyanis természetszerüleg nemcsak elméleti tanulságai miatt fontos. Ez egyúttal a nemzetközi tudományos élet vérkeringéséhez való kapcsolódásnak is elengedhetetlen - az egyre erősödő nemzetközi látókörrel és kapcsolatrendszerrel rendelkező hazai névkutatás számára (vö. FARKAS 2015a: 33-41) tehát egyre fontosabbá váló - feltétele.

\section{Hivatkozott honlapok}

ICOS honlap $=$ https://www.icosweb.net/drupal/

ICOS terminológia $=$ https://icosweb.net/drupal/terminology

UNGEGN honlap $=\underline{\text { https://unstats.un.org/unsd/geoinfo/UNGEGN/ }}$

UNGEGN terminológia $=$ https://unstats.un.org/unsd/geoinfo/UNGEGN/publications.html

\section{Hivatkozott irodalom}

BAUKO JÁNOS 2009. Ragadványnév-vizsgálatok kétnyelvü környezetben. (Négy szlovákiai magyar település ragadványnévrendszere). Konstantin Filozófus Egyetem Közép-európai Tanulmányok Kara - Magyar Nyelvtudományi Társaság, Nyitra-Budapest.

BAUKO JÁNOS 2012. A magyar és a szlovák (szláv) névtani terminológia összevetése. Névtani Értesitő 34: 157-166.

BAUKO JÁNOS 2015a. Bevezetés a szocioonomasztikába. Nyitrai Konstantin Filozófus Egyetem Közép-európai Tanulmányok Kara, Nyitra.

BAUKo JÁNOs 2015b. Magyar névkutatás a határokon túl. In: FARKAS TAMÁs - Slíz MARIANN szerk., Magyar névkutatás a 21. század elején. Magyar Nyelvtudományi Társaság - ELTE Magyar Nyelvtudományi és Finnugor Intézet, Budapest. 63-89.

BAUKO, JÁN [JÁNOS] 2015c. Komparácia slovenských a mad’arských onomastických termínov. In: BALlEKOVÁ, KATARÍNA - KRÁLIK, L'UBOR - MúcsKovÁ, Gabriela eds., Jazykovedné štúdie XXXII. Prirodzený vývin jazyka a jazykové kontakty. Veda, Bratislava. 254-262.

BENKÖ LORÁND 1960. Megjegyzések terminus technikusokról. Magyar Nyelv 56: 238-40.

BEZlAJ, FranCE et al. 1983. Osnoven sistem i terminologija na slovenskata onomastika. Osnovnaja sistema i terminologija slavjanskoj onomastiki. Grundsystem und Terminologie der slawischen Onomastik. Makedonska akademija na naukite i umetnostite - Megunaroden komitet na slavistite - Komisija za slovenska onomastika, Skopje.

BÖLCSKEI ANDREA 2010. A magyar településnevek korrelációs rendszerének alakulása a természetes névadás korszakában. A Károli Gáspár Református Egyetem Magyar Nyelvtudományi Tanszékének Kiadványai 2. Károli Gáspár Református Egyetem Magyar Nyelvtudományi Tanszéke, Budapest.

BÖLCSKEI ANDREA 2012. A helynév-standardizáció terminológiájáról. Névtani Értesitö 34: 167-178. 
BÖLCSKEI ANDREA 2013a. Az „UNGEGN Glossary of Terms for the Standardization of Geographical Names" címü terminusjegyzék magyar változatának elkészítéséröl. Névtani Értesitő 35: 11-21.

BÖLCSKEI ANDREA 2013b. Challenges in updating the Hungarian terminology for geographical names standardization. Magyar Terminológia 6/2: 153-168. https://doi.org/10.1556/1206.2013. $\underline{6.2 .3}$

BÖLCSKEI ANDREA 2017. Két nemzetközi névtani terminológiai jegyzék magyar változata. In: BÖlCSKeI ANDREA - FARKAS TAMÁs - Slíz MARIANn szerk., Magyar és nemzetközi névtani terminológia / Hungarian and International Onomastic Terminology. International Council of Onomastic Sciences - Magyar Nyelvtudományi Társaság, Uppsala-Budapest. 49-61. https://doi. org/10.26546/5061110.8

BölCSKEI ANDREA - FÓRIS ÁGOTA 2012. Névtan és terminológia 2: Névtan és egységesítés. Névtani Értesitö 34: 125-126.

Brendler, Andrea - Brendler, Silvio Hrsg. 2004. Namenarten und ihre Erforschung. Ein Lehrbuch für das Studium der Onomastik. Lehr- und Handbücher zur Onomastik 1. BaarVerlag, Hamburg.

BuCSKO-TKACSOVA 2012. = БУЧКО, ДМИТРО ГРИГОРОВИЧ - ТКАЧОВА, НАТАЛІЯ ВАСИЛІВНА 2012. Словник украӥнської ономастичної термінологї̈. Ранок, Харків.

DORION, Henri - PoIrier, JeAn 1975. Lexique des termes utiles à l'étude des noms de lieux. French and European Publications Inc., Quebec.

FÁBIÁN, ZsUZSANNA 2001. Glossario dei termini piú importanti dell'Onomastica. In: FÁBIÁn, Zsuzsanna ed., Antologia di Onomastica Italiana. Eötvös Loránd Tudományegyetem Bölcsészettudományi Kar Olasz Nyelv és Irodalom Tanszék, Budapest. 291-299.

FARKAS TAMÁS 2008. Szemlélet és terminológia a névkutatásban: a hivatalos magyar családnévváltoztatások kérdései. In: BölCSKEI ANDREA - N. CSÁSZI ILDIKÓ szerk., Név és valóság. $A$ VI. Magyar Névtudományi Konferencia elöadásai. Balatonszárszó, 2007. június 22-24. A Károli Gáspár Református Egyetem Magyar Nyelvtudományi Tanszékének Kiadványai 1. Károli Gáspár Református Egyetem Magyar Nyelvtudományi Tanszéke, Budapest. 332-341.

FARKAS TAMÁS 2011. Terminológiai munkálatok a névkutatás területén. Névtani Értesitô 33: 203-212.

FARKAS TAMÁS 2012. Szempontok a magyar névtani terminológia megítéléséhez. Névtani Értesitö 34: 139-148.

FARKAS TAMÁS 2013. Egy magyar névtani terminológiai szótár tervéröl. In: TóTH SzERGEJ szerk., Társadalmi változások - nyelvi változások. Alkalmazott nyelvészeti kutatások a Kárpátmedencében. A XXII. MANYE Kongresszus elöadásai. Szeged, 2012. április 12-14. A MANYE Kongresszusok Előadásai 9. MANYE - Szegedi Egyetemi Kiadó Juhász Gyula Felsőoktatási Kiadó, Budapest-Szeged. 442-445.

FARKAS TAMÁs 2014a. Dimenzionális szemlélet a névkutatásban. Általános kérdések és a családnévkutatás példája. Névtani Értesitó 36: 9-22.

FARKAS, TAMÁs 2014b. Onomastic Terminology in Hungarian - Situation, Problems and Needs. In: Tort i Donada, JoAn - Montagut i Montagut, Montserrat eds., Els noms en la vida quotidiana. Actes del XXIV Congrés Internacional d'ICOS sobre Ciències Onomàstiques. / Names in daily life. Proceedings of the XXIV ICOS International Congress of Onomastic Sciences. Biblioteca Tècnica De Política Lingüística 11. Generalitat de Catalunya, Barcelona. 14-20. http://www.gencat.cat/llengua/BTPL/ICOS2011/003.pdf és https://doi.org/10.2436/15. $\underline{8040.01 .3}$ 
FARKAS TAMÁS 2015a. A nemzetközi névkutatás és magyar kapcsolatai. In: FARKAS TAMÁs - SLíz MARIANN szerk., Magyar névkutatás a 21. század elején. Magyar Nyelvtudományi TársaságELTE Magyar Nyelvtudományi és Finnugor Intézet, Budapest. 23-47.

FARKAS TAMÁS 2015b. A magyar családnevek változástipológiájáról. Magyar Nyelv 111: 395-408. https://doi.org/10.18349/MagyarNyelv.2015.4.395

FeHÉRTÓi KATALIN 1966. A német névtudomány két újdonsága. Magyar Nyelv 62: 245-247.

N. FodOR JÁNOS 2010. Személynevek rendszere a kései ómagyar korban. A Felsö-Tisza-vidék személyneveinek nyelvi elemzése (1401-1526). Magyar Névtani Értekezések 2. ELTE BTK Magyar Nyelvtörténeti, Szociolingvisztikai, Dialektológiai Tanszéke, Budapest.

N. FODOR JÁNOS 2014. A történeti személynévföldrajz mint a nyelvföldrajz egyik kutatási területe I. A nyelvföldrajzi módszer a névtani kutatásokban. Névtani Értesitő 36: 23-41.

FÖLDI ERVIN 1979. Elöterjesztés a tenger alatti domborzati nevekről. A Földrajzinév-bizottság 32. ülésének jegyzőkönyve. Kézirat, Budapest.

FÖLDI ERVIN 1992. ENSZ földrajzinév-egységesítési szakkifejezések szótára. Névtani Értesitő 14: $127-138$.

Galkowski, ARTUR 2010. Problemi di terminologia onomastica. Contributi per un dibattito. Rivista Italiana di Onomastica 16: 604-624.

GAŁKOWSKI, ARTUR 2012. Aktualizowana lista podstawowych haset terminologii onomastycznej w języku polskim. http://onomastyka.uni.lodz.pl/strona-glowna/terminologia-polska

B. Gergely Piroska 2007. Hajdú Mihály: Általános és magyar névtan. Magyar Nyelvőr 131: $253-258$.

GYÖRFFY ERZSÉBET 2007. A svéd névtudományról és helynévkutatásról. Névtani Értesitő 29: $247-257$.

GYÖRFFY ERZSÉBET 2012. A hivatalos név terminus. Magyar Nyelvjárások 50: 27-35.

HAJdú MıHÁLy 1974a. Vitainditó a névtudomány müszavairól. Bokor Levelek 12. Sokszorosított kiadvány, Budapest.

HAJDÚ MıHÁLY 1974b. Előterjesztés a magyar névtudomány müszavainak egységesitéséről. Sokszorosított kiadvány, Budapest.

HAJdÚ MiHÁLY 1979. A magyar névtudomány müszavai. Névtani Értesitő 2: 18-28.

HaJdú MiHÁLy 1981. J. Soltész Katalin, A tulajdonnév funkciója és jelentése. Magyar Nyelv 77: $109-113$.

Hajdú Mihály 2002. Tulajdonnév és dialektológia. In: SZABó GÉZA - MolnÁR Zoltán GutTMAnn MikLós szerk., IV. Dialektológiai Szimpozion. Szombathely, 2001. augusztus 23-25. A Berzsenyi Dániel Tanárképző Főiskola Magyar Nyelvészeti Tanszékének Kiadványai V. Berzsenyi Dániel Föiskola Magyar Nyelvészeti Tanszéke, Szombathely. 104-119.

HAJdú MihÁly 2003. Általános és magyar névtan. Személynevek. Osiris Kiadó, Budapest.

Hajdú MihÁly 2006. Álnév - fedőnév - jelige - internetnév. In: MÁRTONFi AtTila - PAPP KornÉlia - Slíz Mariann szerk., 101 írás Pusztai Ferenc tiszteletére. Argumentum, Budapest. 257-66.

HAJDÚ MiHÁLy 2009. A névváltozások és névváltoztatások rendszere. In: FARKAS TAMÁs - KozMA IsTVÁN szerk., A családnév-változtatások történetei időben, térben, társadalomban. Gondolat Kiadó - Magyar Nyelvtudományi Társaság, Budapest. 29-40.

Hajdú MinÁly 2010. Közös tervek Mező Andrással. In: P. LAKATos IlonA - Sebestyén Zsolt szerk., Emlékkönyv Mezö András tiszteletére. Bessenyei Könyvkiadó, Nyíregyháza. 23-28.

HAJdú MıHÁLy 2011. Farkas Tamás, Családnév-változtatás Magyarországon. Magyar Nyelv 107: 345-347. 
HÁRi GyUla 2010. Épületnév, építménynév, létesítménynév. Névtani Értesitő 32: 99-116.

HaRVALíK, MiLAN 2005. Towards a new millennium - towards a common onomastic terminology? In: Brylla, Eva - WAHLberg, MAts eds., Proceedings of the 21st International Congress of Onomastic Sciences. Uppsala 19-24 August 2002. Språk- och folkminnesinstitutet, Uppsala. 1: $160-171$.

HARVALíK 2007. = ГАРВАлИК, МилАН 2007. К вопросу о современной ономастической терминологии. Вопросы ономастики 4: 5-13.

HaRVALíK, Milan 2014. Towards a common onomastic terminology? The next step. In: TORT Donada, Joan - Montagut i Montagut, Montserrat eds., Els noms en la vida quotidiana. Actes del XXIV Congrés Internacional d'ICOS sobre Ciències Onomàstiques. / Names in daily life. Proceedings of the XXIV ICOS International Congress of Onomastic Sciences. Biblioteca Tècnica De Política Lingüística 11. Generalitat de Catalunya, Barcelona. 21-25. http://www. gencat.cat/llengua/BTPL/ICOS2011/004.pdf és https://doi.org/10.2436/15.8040.01.4

HaRVALÍK, Milan - CAFFARELli, EnZO 2007. Onomastic terminology: an international survey / Terminologia onomastica: un'inchiesta internazionale. Rivista Italiana di Onomastica 13: 181-220.

HENNO, KAIRIT - PÄLL, PEETER 2003. Onomastika termineid. http://www.eki.ee/nimeselts/nimeterm.htm

Hoffmann István 1993. Helynevek nyelvi elemzése. A Debreceni Kossuth Lajos Tudományegyetem Magyar Nyelvtudományi Intézetének Kiadványai 61. Debreceni Kossuth Lajos Tudományegyetem Magyar Nyelvtudományi Intézete, Debrecen.

HofFMANN IstvÁN 1999. A helynevek rendszerének nyelvi leírásához. Magyar Nyelvjárások 37 207-216.

HofFMANN IsTVÁN 2002. Magyar névkutatás az ezredfordulón. In: HofFMANN IsTVÁN - JUHÁsz DEZSÖ - PÉNTEK JÁNOS szerk., Hungarológiai és dimenzionális nyelvszemlélet. Elöadások az V. Nemzetközi Hungarológiai Kongresszuson. K. n., Debrecen-Jyväskylä. 9-22.

HofFMANN IstVÁn 2003. Magyar helynévkutatás 1958-2002. A Magyar Névarchívum Kiadványai 7. Debreceni Egyetem Magyar Nyelvtudományi Tanszék, Debrecen.

HoFFMANN ISTVÁN $2007^{2}$. Helynevek nyelvi elemzése. Segédkönyvek a nyelvészet tanulmányozásához 67. Tinta Könyvkiadó, Budapest.

HoFFMANN IsTVÁN 2008. A személynévrendszerek leírásához. Magyar Nyelvjárások 46: 5-20.

HoFFMANN ISTVÁN 2012. Elmélet és terminológia a magyar helynévkutatásban. Névtani Értesitő 34: 127-137.

HOFFMANN, ISTVÁN - TÓTH, VALÉRIA 2015. Viewpoints on the cognitive-pragmatic description of personal names. Word: Journal of the International Linguistic Association 61: 141-164. https://doi.org/10.1080/00437956.2015.1033832

JuHÁsz DEZsŐ 2004. A névtan néhány terminológiai és tudományrendszertani kérdéséről. In: FARKAS FERENC szerk., Magyar névtani kutatások itthon és határainkon túl. Névtani tanácskozás Jászberényben. 2003. október 17-18. Magyar Nyelvtudományi Társaság - Szent István Egyetem Jászberényi Főiskolai Kar - TIT Jászsági Szervezete - Jászok Egyesülete, Budapest. 165-169.

JuHÁsz DEZső 2010. A személynevek mint a nyelvföldrajz tárgyai. In: VöRÖs FERENC szerk., A nyelvföldrajztól a névföldrajzig. A 2010. június 8-i szombathelyi tanácskozás elöadásai. A Magyar Nyelvtudományi Társaság Kiadványai 234. Magyar Nyelvtudományi Társaság - NyME Savaria Egyetemi Központ, Budapest-Szombathely. 31-39.

KAlETA, ZoFiA 1998. Kierunki i metodologia badań. Terminologia. In: RZETELSKA-FELESZKo, EwA ed., Polskie nazwy własne. Encyklopedia. Wydawnictwo Instytutu Języka Polskiego PAN, Warszawa-Kraków. 45-81. 
KÁlmÁn BÉla 1982. Névtani Értesítő. Szerk. Hajdú Mihály és Mező András. 2-5. szám. Magyar Nyelv 78: 502-505.

Kiviniemi, EERO - PitKÄNEN, RitVA-LiISA - ZilliaCUS, KuRT eds. 1974. Nimistöntutkimuksen terminologia. Terminologin inom namnforskningen. Castrenianumin toimitteita 8. Castrenianum, Helsinki.

KOROMPAY KLÁRA 2011. Az irodalmi névadás fogalmáról. Létünk 41/3: 86-93.

Kovalovszky Miklós 1934. Az irodalmi névadás. A Magyar Nyelvtudományi Társaság Kiadványai 34. Magyar Nyelvtudományi Társaság, Budapest.

Marcato, CARLa 2009. Nomi di persona, nomi di luogo. Introduzione all'onomastica italiana. Il Mulino, Bologna.

MÁRTON MÁTYÁs 1992. A magyar tengerfenék-domborzati nevek megalkotásáról. Névtani Értesitő 14: 84-116.

MÁRTON MÁTYÁs 2012. A világtenger kartográfus szemmel. Eötvös Loránd Tudományegyetem Informatikai Kar Térképtudományi és Geoinformatikai Tanszék, Budapest.

MÁRTON MÁTYÁs - DuTKÓ ANDRÁs ÁKOS szerk. 2003. Standardization of Undersea Feature Names / Tengerfenék-domborzati képződmények neveinek egységesitése. Angol-magyar változat. Kézirat, Budapest.

MiKeSY SÁNDOR 1959. Írói névadás - irodalmi névadás. Magyar Nyelv 55: 110-112.

MiKeSY SÁNDOR 1960. Mi legyen az onomasztika magyar neve? Magyar Nyelv 56: 236-238.

MizSER LAJOS 1979. Három finn névtudományi munka. Magyar Nyelv 75: 246-250.

NiMCSUK 1966 = НІмчУк, ВАСиль ВАСильович 1966. Українська ономастична термінологія. Повідомлення Украӥнської ономастичної комісії 1: 24-43.

NYSTRÖM, STAFFAN 2014. The terminological work of UNGEGN and ICOS - a presentation and a comparison. In: TORT I DONADA, JOAN - MONTAGUT I MONTAGUT, MONTSERRAT eds., Els noms en la vida quotidiana. Actes del XXIV Congrés Internacional d'ICOS sobre Ciències Onomàstiques. / Names in daily life. Proceedings of the XXIV ICOS International Congress of Onomastic Sciences. Biblioteca Tècnica De Política Lingüística 11. Generalitat de Catalunya, Barcelona. 52-57. http://www.gencat.cat/llengua/BTPL/ICOS2011/008.pdf és https://doi.org/10.2436/15.8040.01.8

ÖRDÖG FERENC 1989. Helynévgyüjteményeink mint az onomatodialektológia forrásai. Baranyai Müvelödés 1989/3: 27-33.

ÖRDÖG FERENC 1991. Személyneveink onomato-dialektológiai vizsgálatáról. In: HAJDÚ MiHÁLY szerk., Emlékkönyv Benkö Loránd hetvenedik születésnapjára. ELTE, Budapest. 488-496.

ÖRDÖG FERENC 2010. Névföldrajz, onomatodialektológia, névdialektológia. In: VöRÖs FERENC szerk., A nyelvföldrajztól a névföldrajzig. A 2010. június 8-i szombathelyi tanácskozás elöadásai. A Magyar Nyelvtudományi Társaság Kiadványai 234. Magyar Nyelvtudományi Társaság, Budapest-Szombathely. 127-133.

PAPP LÁszló 1955. Szabó István: Bács, Bodrog és Csongrád megye dézsmalajstromai 1522-ből. Magyar Nyelv 51: 258-263.

PETR, JAN 1969. Lužickosrbská onomastická terminologie. Zpravodaj Mistopisné komise ČSAV 10: 538-552.

PODOLSZKAJA $1978^{1}=$ ПОДОЛЬСКАЯ, НАТАЛЬЯ ВЛАДИМИРОВНА $1978^{1}$. Словарь русской ономастической терминологии. Наука, Москва.

PODOLSZKAJA $1988^{2}$ = ПодОЛЬСКАЯ, НАТАЛЬЯ ВЛАДИМИРОВНА $1988^{2}$. Словарь русской ономастической терминологии. Наука, Москва.

PoKOly BÉLA 2013. Az exonima kifejezés értelmezésének változása a földrajzinév-egységesítés nemzetközi gyakorlatában. Névtani Értesítö 35: 71-75. 
Pokoly, Béla - BölCSKei, Andrea - Mikesy, GÁBOr 2015. The exonym/endonym divide: Examples highlighting different aspects for defining the terms. In: JORDAN, PETER - WoOdMAN, PAUL eds., Confirmation of the Definitions. Proceedings of the 16th UNGEGN Working Group on Exonyms Meeting, Hermagor, 5-7 June 2014. Verlag Dr. Kovac, Hamburg. 155-168.

RAÁTZ JUDIT 1999. Intern Otto, Angicica, Lütyő és a többiek, azaz névválasztás a számítógépes csevegőcsatornán. Névtani Értesitő 21: 262-266.

RAÁTZ Judit 2008. Névadás az interneten. In: BölCSKEI ANDREA - N. CsÁSZI Ildikó szerk., Név és valóság. A VI. Magyar Névtudományi Konferencia elöadásai. Balatonszárszó, 2007. június 22-24. A Károli Gáspár Református Egyetem Magyar Nyelvtudományi Tanszékének Kiadványai 1. Károli Gáspár Református Egyetem Magyar Nyelvtudományi Tanszéke, Budapest. 443-450.

RoOM, Adrian 1996. An Alphabetical Guide to the Language of Name Studies. The Scarecrow Press, Lanham (MD) - London.

Rzetelska-Feleszko, Ewa - Cieślikowa, Aleksandra - Duma, Jerzy red. 2002-2003. Stowiańska onomastyka. Encyklopedia 1-2. Towarzystwo Naukowe Warszawskie, WarszawaKraków.

SCHMIDT, TOM 1981. Fagordliste for norsk namnegransking. Institutt for namnegransking Universitetet i Oslo, Oslo.

SLíz MarianN 2010. A történeti személynévkutatás terminológiájához. Névtani Értesitő 32: 157-172.

SLíz MARIANN 2012. Terminusok keletkezése és változása. Névtani Értesitő 34: 149-156.

SLíz MARIANN 2014. A terminológiai egységesülés hiányának következményei a névtudományban. In: Lengyel KLÁRA - VeSZELSZKi ÁGNES szerk., Tudomány, technolektus, terminológia. A tudományok, szakmák nyelve. Éghajlat Könyvkiadó, Budapest. 249-258.

SLíz MARIANN 2015. Ảltalános névtani kérdések. In: FARKAS TAMÁs - SLíz MARIANN szerk., Magyar névkutatás a 21. század elején. Magyar Nyelvtudományi Társaság - ELTE Magyar Nyelvtudományi és Finnugor Intézet, Budapest. 93-114.

SLíz MARIANN megj. e. A személynevekkel kapcsolatos névtani és jogi terminológia. Megjelenés elött.

Smith, Elsdon Coles 1967. Treasury of Name Lore. Sketches and Observations on the Names We Bear. Harper \& Row, New York - Evanston - London.

J. SoltÉSZ KATALIN 1979. A tulajdonnév funkciója és jelentése. Akadémiai Kiadó, Budapest.

T. SOMOGYi MAGDA 2015. Az írói névadás vizsgálata. In: FARKAS TAMÁS - SLíz MARIANN szerk., Magyar névkutatás a 21. század elején. Magyar Nyelvtudományi Társaság - ELTE Magyar Nyelvtudományi és Finnugor Intézet, Budapest. 207-226.

Svoboda, JAN - Šmilauer, Vladimír - OlivovÁ-NeZBedovÁ, LibuŠE - Oliva, Karel - WitKowski, THEODOLIUS 1973. Základní soustava a terminologie slovanské onomastiky. Grundsystem und Terminologie der slawischen Onomastik. Zpravodaj Mistopisné komise ČSAV 14: 1-280.

SzENTGYÖRGYI RUdOLF 2016. A Tihanyi alapítólevél személynevei III. Személynevek és helynevek kapcsolata. Névtani Értesitö 38: 9-18.

TAKÁCS JUDIT megj. e. Finn-magyar kontrasztív névtani (terminológiai) vizsgálatok a személynévtípusok megnevezésének köréből. Megjelenés előtt.

TóTH LÁszLó 2015. Alapfogalmak az irodalmi onomasztikában. Acta Academiae Agriensis Sectio Linguistica Hungarica 42: 203-215.

Tóth, VALÉRIA 2005. The Changes of the Hungarian Settlement Names. In: MATICSÁK, SÁNDOR ed., Settlement Names in the Uralian Languages. Onomastica Uralica 3. K. n., DebrecenHelsinki. 135-153. 
TÓTH VALÉRIA 2008. Településnevek változástipológiája. A Magyar Névarchívum Kiadványai 14. Debreceni Egyetem Magyar Nyelvtudományi Tanszéke, Debrecen.

UdVARI ISTVÁN 1981. Н. В. Подольская: Словарь русской ономастической терминологии. Névtani Értesitö 6: 71-3.

VÁCZINÉ TAKÁCs EDIT 2016. Az irói névadás sajátosságai Karinthy Frigyes müvei alapján bemutatva. Doktori (PhD) értekezés. ELTE BTK, Budapest. https://doi.org/10.15476/ELTE.2016.147

VÁRnAi Judit SzILvia 2005. Bárhogy nevezzük... A tulajdonnév a nyelvben és a nyelvészetben. Segédkönyvek a nyelvészet tanulmányozásához 42. Tinta Könyvkiadó, Budapest.

VÁRNAI JUdit SzILVIA szerk. é. n. Angol-magyar nyelvészeti glosszárium / English-Hungarian glossary of linguistical terms. http://mnytud.arts.klte.hu/glossary.htm és http://mnytud.arts.klte. hu/glosseng.htm

VASILEVA, NATALIA 2014. Koordinierung der onomastischen Terminologie: die Suche nach der lexikographischen Lösung. In: Tort i Donada, JoAN - Montagut i Montagut, Montserrat eds., Els noms en la vida quotidiana. Actes del XXIV Congrés Internacional d'ICOS sobre Ciències Onomàstiques. / Names in daily life. Proceedings of the XXIV ICOS International Congress of Onomastic Sciences. Biblioteca Tècnica De Política Lingüística 11. Generalitat de Catalunya, Barcelona. 99-106. http://www.gencat.cat/llengua/BTPL/ICOS2011/013.pdf és https://doi.org/10.2436/15.8040.01.13

VINCZE LÁSZLÓ 2004. A magyar belterületi helynevek kutatásában elért eddigi eredmények és további feladatok (A hazai és külföldi teljesítmények összevetése). In: FARKAS FERENC szerk., Magyar névtani kutatások itthon és határainkon túl. Névtani tanácskozás Jászberényben. 2003. október 17-18. Magyar Nyelvtudományi Társaság - Szent István Egyetem Jászberényi Főiskolai Kar - TIT Jászsági Szervezete - Jászok Egyesülete, Budapest. 187-191.

VÖRÖS FERENC 2009. Névváltoztatás és névhelyreállitás a kisebbségi magyar névhasználat tükrében: terminológiai javaslat egy névtani jelenség megnevezésére. In: FARKAS TAMÁs - KOZMA IsTVÁN szerk., A családnév-változtatások történetei idöben, térben, társadalomban. Gondolat Kiadó Magyar Nyelvtudományi Társaság, Budapest. 57-74.

WALTHER, HANS 1998. Namenkunde und geschichtliche Landeskunde 2. Erläuterung namenkundlicher Fachbegriffe. Universität Leipzig Institut für Slavistik, Leipzig.

WitKowsKi, TEODOLIUs 1964. Grundbegriffe der Namenkunde. Akademie Verlag, Berlin.

Witkowski, Teodolius 1995. Probleme der Terminologie. In: Eichler, ERnST et al. eds., Namenforschung / Name Studies / Les noms propres. Ein internationales Handbuch zur Onomastik / An International Handbook of Onomastics / Manuel international d'onomastique. Handbücher zur Sprach- und Kommunikationswissenschaft 11. Walter de Gruyter, Berlin - New York. 1: $288-294$.

FARKAS TAMÁS

ORCID: 0000-0002-7732-2302

ELTE Eötvös Loránd Tudományegyetem Magyar Nyelvtudományi és Finnugor Intézet Budapest 